\title{
Effect of Ethylene on Qualitative Changes during Ripening of Mango (Mangifera indica L.) cv. Kesar
}

\author{
N.D. Doke, J.K. Dhemre* and V.P. Kad \\ Post-Harvest Technology Centre, Mahatma Phule Krishi Vidyapeeth, Rahuri-413722 Dist: \\ Ahmednagar, Maharashtra, India \\ *Corresponding author
}

\begin{tabular}{|c|}
\hline Keywords \\
\hline $\begin{array}{l}\text { Mango, Ripening, } \\
\text { Ethylene, Ethephon, } \\
\text { Quality }\end{array}$ \\
\hline Article Info \\
\hline $\begin{array}{l}\text { Accepted: } \\
\text { 15 January } 2018 \\
\text { Available Online: } \\
10 \text { February } 2018\end{array}$ \\
\hline
\end{tabular}

\section{A B S T R A C T}

Mango fruit $\mathrm{Cv}$. Kesar were exposed to ethylene gas (100 ppm) for 12, 18 and $24 \mathrm{hrs}$ in fruit ripening chamber and were then removed from the ripening chamber at the end of exposure period, packed in corrugated fibre board boxes and then kept at ambient condition to study the ripening behaviour. In another trial, the mango fruits were treated with ethephon at the concentration of 500,750 and $1000 \mathrm{ppm}$ for five minutes, drained, packed in corrugated fibre board boxes and then kept at ambient condition. It was found that mango $\mathrm{Cv}$. Kesar exposed to the ethylene gas in the ripening chamber and ethephon dip treatment triggered the ripening process. It was also noticed that more the period of exposure to ethylene gas and more the concentration of ethephon, faster was the ripening process and showed the significant increasing trends in TSS, sugars, $\beta$ carotene, and decreasing trends in titratable acidity and ascorbic acid in all the treatment combinations during advancement of storage period. It was observed that mango fruits $\mathrm{Cv}$. Kesar ripened by exposing them to $100 \mathrm{ppm}$ ethylene gas in ripening chamber for $18 \mathrm{hrs}$ and storage at ambient condition recorded the maximum shelf life of 6 days and showed better results in respect of high overall acceptability score of 8.77 . Similarly, mango fruits ripened by ethephon dip treatment of $750 \mathrm{ppm}$ for 5 minutes and storage at ambient condition recorded the maximum shelf life of 8 days and showed better results in respect of high overall acceptability score of 8.66 , respectively. The cost of ripening chamber for $800 \mathrm{~kg}$ fruits on per day interest and ethylene gas was considered for calculating the cost of ripening. The cost was found to be Rs. 0.69 per $\mathrm{kg}$.

\section{Introduction}

Mango (Mangifera indica L.) belongs to family Anacardiaceae is the national fruit of India and rightly known as the 'King of fruits' owing to its attractive colour, excellent taste, excellent flavour, exemplary nutritive value, processing qualities and its delicacy for the table which provides employment to the millions of poor people during summer. The research efforts have helped to increase the production of mango fruits but the purpose of obtaining maximum profit will not be served unless the increased production is supplemented with similar efforts to minimize their post-harvest losses, which range between 25-30 per cent. India ranks first in the world with total production of 18.31 million tonnes 
from about 2.5 million hectares and productivity is 7.3 tonnes/ha.

The annual production of mango followed by India are China, Thailand, Indonesia, Mexico, Pakistan and Brazil as 4.40, 2.65, 2.37, 1.70, 1.95 and 1.17 million tonnes, respectively.

Uttar Pradesh is leading state with 4.30 million tonnes of mango production followed by Andhra Pradesh (2.73), Karnataka (1.79), Bihar (1.36), Maharashtra (1.21), Gujarat (1.12), and Orissa (0.75) which are the major mango growing states in India (Anon., 2014).

Artificial ripening of mango is very recent concept in post-harvest technology but it has great importance especially in export of mango. The ripening with ethylene gas or ethephon treatment seems to hold promise to get good and uniform quality. Therefore, the present investigation was carried out with the objective to study the effect of ethylene on qualitative changes during ripening behaviour of mango Cv. Kesar.

\section{Materials and Methods}

The present research entitled "Effect of ethylene on qualitative changes during ripening of mango (Mangifera indica L.) Cv. Kesar." was carried out in the Post-Harvest Technology Centre, Department of Horticulture, Mahatma Phule Krishi Vidyapeeth, Rahuri during the year 2014 2015.

\section{Selection of fruits}

Physiologically mature, healthy green fruits at optimum maturity of mango Cv. Kesar were collected from mango orchard, Department of Horticulture, Mahatma Phule Krishi Vidyapeeth, Rahuri. Harvested fruits were washed, treated and packed in CFB and were used for further investigation.

\section{Ripening chamber}

The ripening chamber made up of polypropelene with a dimension of $7 \times 7 \times 7$ ' having capacity to hold 500-700 kg of mango fruits supported with a frame of 1.5 " PVC pipes with a thickness of $0.33 \mathrm{~mm}$.

\section{Ethylene gas cylinder}

Ethylene is a natural ripening hormone used for mango ripening in low cost ripening chamber at the concentration of $100 \mathrm{ppm}$.

\section{Ethephon}

Ethephon 39\% SL for dip treatment was used under the brand name ethefol.

\section{Post-harvest treatments}

\section{Ethylene gas}

The selected mango fruits Cv. Kesar were kept in low cost fruit ripening chamber in the PostHarvest Technology Centre, Department of Horticulture, MPKV, Rahuri. The concentration of ethylene gas in the ripening chamber for each treatment was kept as 100 ppm, as per method developed by (Pujari and Mehta, 2010). The mango fruits were exposed to the ethylene gas in ripening chamber (29.4$31.9^{0} \mathrm{C}$ with $65-84 \%$ R.H) for certain period (Table 1) as per treatment and untreated fruits were kept at ambient temperature. The fruits were then removed from the ripening chamber at the end of exposure period and then kept at ambient condition $\left(26.8-30.6^{\circ} \mathrm{C}\right.$ with 54.0 $62.6 \%$ R.H) for studying the ripening behaviour of mango fruits.

\section{Ethephon dip treatment}

The selected mango fruits were treated with ethephon dip for 5 minutes at different concentrations as given in Table 1. The treated 
fruits were then drained, packed in corrugated fibreboard boxes and kept at ambient condition $\left(26.8-30.6^{0} \mathrm{C}\right.$ with $54.0-62.6 \%$ R.H) for further study.

\section{Statistical analysis}

The data obtained in the present investigation were analyzed for the statistical significance as suggested by Panse and Sukhatme (1995).

\section{Results and Discussion}

\section{Chemical composition of fresh mango fruit}

The results for physico-chemical properties of fresh (unripe) mango fruit $\mathrm{Cv}$. Kesar revealed that the fresh (unripe) mango had $6.86^{\circ} \mathrm{B}$ total soluble solids, 2.08 per cent acidity, 2.15 per cent reducing sugars, 4.35 per cent total sugars, $88.40 \mathrm{mg} / 100 \mathrm{~g}$ ascorbic acid and $268 \mu \mathrm{g} / 100 \mathrm{~g} \beta$ carotene, respectively. The research findings are comparable with the observations reported by Deepa and Preetha (2014) and Venkatram and Pandiarajan (2014) in mango fruit. The TSS, total sugars, reducing sugars and $B$ carotene was found to be increased statistically whereas titratable acidity and ascorbic acid was found to be statistically decreased in all the treatments during the advancement of storage period (Table 2).

\section{Total soluble solids (TSS) $\left({ }^{0} \mathrm{~B}\right)$}

At the initial stage, the TSS of mango fruit was found to be $6.86^{\circ}$ Brix. At the end of $2^{\text {nd }}$, $4^{\text {th }}$ and $6^{\text {th }}$ day of storage, treatment $T_{4}$ recorded maximum TSS (10.50, 14.75 and $19.67^{0}$ Brix $)$ followed by treatment $\mathrm{T}_{3}(9.97$, $12.65,19.67{ }^{0}$ Brix) in ethylene gas exposure treatment in the ripening chamber. At the end of $8^{\text {th }}$ day of storage, the treatment $\mathrm{T}_{3}$ recorded maximum TSS $\left(19.42^{\circ}\right.$ Brix $)$ followed by treatment $\mathrm{T}_{2}\left(19.30^{\circ} \mathrm{Brix}\right)$ in ethylene gas exposure treatment in the ripening chamber.
At the end of $2^{\text {nd }}, 4^{\text {th }}$ and $6^{\text {th }}$ and $8^{\text {th }}$ day of storage, treatment $\mathrm{T}_{7}$ recorded maximum TSS (9.86, 14.18, 19.30 and $19.55{ }^{\mathbf{0}}$ Brix) followed by treatment $\mathrm{T}_{6}(9.35,11.92,14.78$ and 19.30 ${ }^{0}$ Brix) in ethephon dip treatments.

The TSS might be increased due to hydrolysis of starch, cellulose and pectin substances into simpler substances or might be due to decrease in moisture content. Similar results were also reported by Sakhale et al., (2006), Pandarinathan and Sivakumar (2010), Venkatram and Pandiarajan (2014), Zagade and Relekar (2014), Patel et al., (2015) in mango fruits.

\section{Titratable acidity (\%)}

At initial stage, the acidity of mango fruit was found to be 2.08 per cent. At the end of $2^{\text {nd }}$, $4^{\text {th }}, 6^{\text {th }}$ and $8^{\text {th }}$ day of storage, treatment $T_{4}$ recorded minimum acidity $(1.41,0.83,0.27$ and $0.22 \%)$ followed by treatment $\mathrm{T}_{3}(1.45$, 1.07, 0.67 and $0.27 \%$ ) in ethylene gas exposure treatment in the ripening chamber.

At the end of $2^{\text {nd }}, 4^{\text {th }}, 6^{\text {th }}$ and $8^{\text {th }}$ day of storage, treatment $\mathrm{T}_{7}$ recorded minimum acidity $(1.60,1.06,0.25$ and $0.19 \%)$ followed by treatment $\mathrm{T}_{6}(1.65,1.18,0.68$ and $0.23 \%)$ in ethephon dip treatments. At end of $8^{\text {th }}$ day of storage, treatments $\mathrm{T}_{3}$ and $\mathrm{T}_{5}$ recorded acidity as 0.27 and $0.28 \%$, respectively which were at par with each other. This might be due to faster degradation of organic acids into sugars and utilization of acids during respiration. The results obtained in present study are in conformity with the observations of Sakhale et al., (2006) and Deepa and Preetha (2014) in mango fruits.

\section{Ascorbic acid (mg/100 g)}

At the initial stage, the ascorbic acid content of mango fruit was found to be $88.40 \mathrm{mg} / 100 \mathrm{~g}$. At the end of $2^{\text {nd }}, 4^{\text {th }}, 6^{\text {th }}$ and $8^{\text {th }}$ day of 
storage, treatment $\mathrm{T}_{4}$ recorded minimum ascorbic acid (68.55, 55.37, 35.32 and 33.20 $\mathrm{mg} / 100 \mathrm{~g}$ ) followed by treatment $\mathrm{T}_{3}$ (71.52, $58.45,45.12$ and $36.30 \mathrm{mg} / 100 \mathrm{~g}$ ) in ethylene gas exposure treatment in the ripening chamber.

At the end of $2^{\text {nd }}, 4^{\text {th }}, 6^{\text {th }}$ and $8^{\text {th }}$ day of storage, treatment $\mathrm{T}_{7}$ recorded minimum ascorbic acid (68.76, 56.32, 36.25 and 35.19 $\mathrm{mg} / 100 \mathrm{~g})$ followed by treatment $\mathrm{T}_{6}$ (73.20, $64.83,51.33$ and $36.66 \mathrm{mg} / 100 \mathrm{~g}$ ) in ethephon dip treatments. At the end of $6^{\text {th }}$ day of storage, treatment $\mathrm{T}_{2}$ and $\mathrm{T}_{6}$ recorded 51.22 and $51.33 \mathrm{mg} / 100 \mathrm{~g}$ and were at par with each other. At the end of $8^{\text {th }}$ day of storage, the treatment $\mathrm{T}_{7}$ recorded minimum ascorbic acid $(\mathrm{mg} / 100 \mathrm{~g})$ followed by treatment $\mathrm{T}_{6}$ $(\mathrm{mg} / 100 \mathrm{~g})$ in ethephon dip treatment.

A decline in ascorbic acid content of the mango fruits might be due to utilization of ascorbic acid in respiration process during ripening at ambient condition. Similar trend was also observed by Sakhale et al., (2006), William et al., (2009), Pandarinathan and Sivakumar (2010), in mango fruits.

\section{Total sugars (\%)}

At initial stage, the total sugars content of mango fruit was found to be 4.35 per cent. At the end of $2^{\text {nd }}, 4^{\text {th }}$, and $6^{\text {th }}$ day of storage, treatment $\mathrm{T}_{4}$ recorded maximum total sugars content $(9.07,12.63,16.65 \%)$ followed by treatment $\mathrm{T}_{3}(8.88,11.28$ and $13.83 \%)$. At the end of $8^{\text {th }}$ day of storage, the treatment $T_{3}$ recorded maximum total sugars content $(16.82 \%)$ in ethylene gas exposure treatment in the ripening chamber.

At the end of $2^{\text {nd }}$ and $4^{\text {th }}$ day of storage, treatment $\mathrm{T}_{7}$ recorded maximum total sugars content (9.18 and $11.70 \%)$ followed by treatment $\mathrm{T}_{6}(8.85$ and $11.63 \%)$ in ethephon dip treatments. At the end of $8^{\text {th }}$ day of storage, the treatment $\mathrm{T}_{7}$ recorded maximum total sugars content (16.90\%) followed by treatment $\mathrm{T}_{6}(16.82 \%)$ in ethephon dip treatments.

The significant increase in the total sugars content may be due to the carbohydrates accumulate during maturation in the form of starch. As the fruit ripens, starch was broken down into sugars. These observations are in conformity with research findings of Pandarinathan and Sivakumar (2010), Singh et al., (2012), Zagade and Relekar (2014) in mango fruits.

\section{Reducing sugars (\%)}

At initial stage, the reducing sugars content of mango fruit was found to be 2.15 per cent. At the end of $2^{\text {nd }}$ and $4^{\text {th }}$ day of storage, treatment $\mathrm{T}_{4}$ recorded maximum reducing sugars content (3.76 and $5.12 \%$ ) followed by treatment $\mathrm{T}_{3}$ (3.46 and $4.78 \%$ ) in ethylene gas exposure treatment in the ripening chamber.

At the end of $6^{\text {th }}$ day of storage, the treatment $\mathrm{T}_{4}$ recorded maximum reducing sugars content $(6.22 \%)$, however it was declined on $8^{\text {th }}$ day $(6.12 \%)$.

At the end of $8^{\text {th }}$ day of storage, the treatment $\mathrm{T}_{3}$ recorded maximum reducing sugars content $(6.18 \%)$ followed by treatment $\mathrm{T}_{4}(6.12 \%)$ in ethylene gas exposure treatment in the ripening chamber.

At the end of $2^{\text {nd }}, 4^{\text {th }}, 6^{\text {th }}$ and $8^{\text {th }}$ day of storage, treatment $\mathrm{T}_{7}$ recorded maximum reducing sugars content $(3.80,4.98,6.14$ and $6.22 \%)$ followed by treatment $\mathrm{T}_{6}(3.48,4.95$, 5.52 and $6.16 \%$ ) in ethephon dip treatments.

At the end of $8^{\text {th }}$ day of storage, treatment $T_{3}$ and $\mathrm{T}_{6}$ recorded reducing sugars as 6.18 and $6.16 \%$ respectively, which were at par each other. 
Table.2 Effect of various treatments on bio- chemical properties of mango during ripening

\begin{tabular}{|c|c|c|c|c|c|c|c|c|c|c|}
\hline \multirow{3}{*}{ Particulars } & \multirow[t]{3}{*}{ Storage period (days) } & \multicolumn{9}{|c|}{ Treatments } \\
\hline & & \multirow{2}{*}{$\begin{array}{c}\text { Control } \\
\mathbf{T}_{1}\end{array}$} & \multicolumn{3}{|c|}{ Ripening chamber } & \multicolumn{3}{|c|}{ Ethephon dip } & \multirow[b]{2}{*}{$\mathbf{S E} \pm$} & \multirow[b]{2}{*}{ C.D. at $5 \%$} \\
\hline & & & $\mathbf{T}_{2}$ & $\mathbf{T}_{\mathbf{3}}$ & $\mathbf{T}_{4}$ & $\mathbf{T}_{5}$ & $\mathbf{T}_{6}$ & $\mathbf{T}_{7}$ & & \\
\hline \multicolumn{11}{|c|}{ Total soluble solids ( $\left.{ }^{0} \mathrm{~B}\right)$} \\
\hline & 2 & 7.85 & 9.55 & 9.97 & 10.50 & 8.94 & 9.35 & 9.86 & 0.02 & 0.06 \\
\hline & 4 & 10.17 & 12.15 & 12.65 & 14.75 & 11.32 & 11.92 & 14.18 & 0.05 & 0.15 \\
\hline & 6 & 12.70 & 15.32 & 15.83 & 19.67 & 14.45 & 14.78 & 19.30 & 0.05 & 0.16 \\
\hline & 8 & 15.81 & 19.30 & 19.42 & 18.25 & 19.13 & 19.30 & 19.55 & 0.06 & 0.21 \\
\hline \multicolumn{11}{|c|}{ Titratable acidity (\%) } \\
\hline & 2 & 1.83 & 1.52 & 1.45 & 1.41 & 1.73 & 1.65 & 1.60 & 0.01 & 0.04 \\
\hline & 4 & 1.45 & 1.15 & 1.07 & 0.83 & 1.25 & 1.18 & 1.06 & 0.01 & 0.04 \\
\hline & 6 & 0.97 & 0.72 & 0.67 & 0.27 & 0.84 & 0.68 & 0.25 & 0.01 & 0.03 \\
\hline & 8 & 0.36 & 0.33 & 0.27 & 0.22 & 0.28 & 0.23 & 0.19 & 0.20 & 0.02 \\
\hline \multicolumn{11}{|c|}{ Total sugars (\%) } \\
\hline & 2 & 5.70 & 8.54 & 8.88 & 9.07 & 8.54 & 8.85 & 9.18 & 0.05 & 0.18 \\
\hline & 4 & 7.37 & 10.63 & 11.28 & 12.63 & 10.67 & 11.63 & 11.70 & 0.13 & 0.42 \\
\hline & 6 & 9.35 & 13.19 & 13.83 & 16.65 & 14.25 & 13.77 & 16.58 & 0.33 & 1.01 \\
\hline & 8 & 13.23 & 16.57 & 16.82 & 15.16 & 16.35 & 16.82 & 16.90 & 0.06 & 0.19 \\
\hline \multicolumn{11}{|c|}{ Reducing sugars $(\%)$} \\
\hline & 2 & 2.54 & 3.22 & 3.46 & 3.76 & 3.17 & 3.48 & 3.80 & 0.01 & 0.04 \\
\hline & 4 & 3.12 & 4.25 & 4.78 & 5.12 & 4.28 & 4.95 & 4.98 & 0.01 & 0.03 \\
\hline & 6 & 4.16 & 5.17 & 5.56 & 6.22 & 5.06 & 5.52 & 6.14 & 0.01 & 0.04 \\
\hline & 8 & 5.20 & 6.05 & 6.18 & 6.12 & 6.01 & 6.16 & 6.22 & 0.01 & 0.03 \\
\hline \multicolumn{11}{|c|}{ Ascorbic acid (mg/100 g) } \\
\hline & 2 & 81.70 & 73.88 & 71.52 & 68.55 & 75.38 & 73.20 & 68.76 & 0.10 & 0.32 \\
\hline & 4 & 76.62 & 62.55 & 58.45 & 55.37 & 66.03 & 64.83 & 56.32 & 0.06 & 0.19 \\
\hline & 6 & 69.33 & 51.22 & 45.12 & 35.32 & 53.47 & 51.33 & 36.25 & 0.06 & 0.20 \\
\hline & 8 & 62.08 & 39.62 & 36.30 & 33.20 & 40.42 & 36.66 & 35.19 & 0.05 & 0.15 \\
\hline \multicolumn{11}{|c|}{$\beta$ carotene $(\mu \mathrm{g} / 100 \mathrm{~g})$} \\
\hline & 2 & 2654.38 & 3344.72 & 3614.30 & 6074.30 & 2904.52 & 3194.34 & 5486.30 & 0.06 & 0.19 \\
\hline & 4 & 4253.20 & 5314.32 & 5805.37 & 10274.85 & 4634.27 & 5064.45 & 9286.23 & 3.79 & 11.49 \\
\hline & 6 & 6250.22 & 8084.25 & 8736.22 & 14760.08 & 6334.38 & 7684.58 & 13100.02 & 0.10 & 0.32 \\
\hline & 8 & 9600.02 & 12810.22 & 13950.21 & 15900.33 & 11300.31 & 11570.25 & 14300.21 & 0.09 & 0.30 \\
\hline
\end{tabular}


Table.1 Treatment details

\begin{tabular}{|c|l|}
\hline \begin{tabular}{c} 
Treatments \\
\hline $\mathrm{T}_{1}$
\end{tabular} & \multicolumn{1}{c|}{ Details } \\
\hline $\mathrm{T}_{2}$ & $12 \mathrm{hrs}$ exposure to ethylene gas $100 \mathrm{ppm}$ in ripening chamber \\
\hline $\mathrm{T}_{3}$ & $18 \mathrm{hrs}$ exposure to ethylene gas $100 \mathrm{ppm}$ in ripening chamber \\
\hline $\mathrm{T}_{4}$ & $24 \mathrm{hrs}$ exposure to ethylene gas $100 \mathrm{ppm}$ in ripening chamber \\
\hline $\mathrm{T}_{5}$ & $500 \mathrm{ppm}$ dip in ethephon for 5 minutes \\
\hline $\mathrm{T}_{6}$ & $750 \mathrm{ppm}$ dip in ethephon for 5 minutes \\
\hline $\mathrm{T}_{7}$ & $1000 \mathrm{ppm}$ dip in ethephon for 5 minutes \\
\hline
\end{tabular}

Table.3 Effect of ethylene gas and ethephon on organoleptic score of mango Cv. Kesar during $6^{\text {th }}$ day of storage

\begin{tabular}{|c|c|c|c|c|c|c|}
\hline \multirow{2}{*}{\multicolumn{2}{|c|}{ Treatments }} & \multicolumn{5}{|c|}{ Organoleptic score } \\
\hline & & Colour & Flavour & Taste & Texture & $\begin{array}{c}\text { Overall } \\
\text { acceptability }\end{array}$ \\
\hline \multicolumn{7}{|c|}{ Control } \\
\hline $\mathrm{T}_{1}$ & Without treatment i.e. control & 7.00 & 7.00 & 6.00 & 6.00 & 6.50 \\
\hline \multicolumn{7}{|c|}{ Ripening chamber } \\
\hline $\mathbf{T}_{2}$ & $12 \mathrm{hrs}$ exposure to ethylene gas & 8.50 & 8.50 & 8.00 & 8.50 & 8.37 \\
\hline $\mathbf{T}_{3}$ & $18 \mathrm{hrs}$ exposure to ethylene gas & 8.80 & 8.75 & 8.75 & 8.80 & 8.77 \\
\hline $\mathbf{T}_{4}$ & $24 \mathrm{hrs}$ exposure to ethylene gas & 8.50 & 8.75 & 8.20 & 8.40 & 8.46 \\
\hline \multicolumn{7}{|c|}{ Ethphon dip } \\
\hline $\mathbf{T}_{5}$ & 500 ppm ethephon dip treatment & 8.00 & 8.00 & 7.75 & 8.00 & 7.93 \\
\hline $\mathrm{T}_{6}$ & 750 ppm ethephon dip treatment & 8.50 & 8.50 & 7.25 & 8.00 & 8.06 \\
\hline $\mathbf{T}_{7}$ & 1000 ppm ethephon dip treatment & 8.25 & 8.50 & 8.25 & 8.00 & 8.25 \\
\hline
\end{tabular}

Table.4 Effect of ethylene gas and ethephon on organoleptic score of mango cv. Kesar during $8^{\text {th }}$ day of storage

\begin{tabular}{|c|c|c|c|c|c|c|}
\hline \multirow{2}{*}{\multicolumn{2}{|c|}{ Treatments }} & \multicolumn{5}{|c|}{ Organoleptic score } \\
\hline & & Colour & Flavour & Taste & Texture & $\begin{array}{l}\text { Overall } \\
\text { acceptability }\end{array}$ \\
\hline \multicolumn{7}{|c|}{ Control } \\
\hline $\mathrm{T}_{1}$ & Without treatment i.e. control & 7.20 & 7.45 & 7.00 & 7.25 & 7.22 \\
\hline \multicolumn{7}{|c|}{ Ripening chamber } \\
\hline $\mathbf{T}_{2}$ & $12 \mathrm{hrs}$ exposure to ethylene gas & 8.40 & 8.50 & 8.25 & 8.50 & 8.40 \\
\hline $\mathbf{T}_{3}$ & $18 \mathrm{hrs}$ exposure to ethylene gas & 8.30 & 8.10 & 8.00 & 8.00 & 8.10 \\
\hline $\mathbf{T}_{4}$ & $24 \mathrm{hrs}$ exposure to ethylene gas & 8.00 & 7.50 & 7.75 & 8.20 & 7.85 \\
\hline \multicolumn{7}{|c|}{ Ethphon dip } \\
\hline $\mathbf{T}_{5}$ & 500 ppm ethephon dip treatment & 8.25 & 8.00 & 8.50 & 8.00 & 8.18 \\
\hline $\mathrm{T}_{6}$ & 750 ppm ethephon dip treatment & 8.70 & 8.60 & 8.75 & 8.60 & 8.66 \\
\hline $\mathbf{T}_{7}$ & 1000 ppm ethephon dip treatment & 8.00 & 8.10 & 7.75 & 7.80 & 7.91 \\
\hline
\end{tabular}


Table.5 Cost of ripening of Kesar mango fruit

\begin{tabular}{|c|c|c|c|c|}
\hline Sr. No. & Particulars & Quantity & Rate (Rs.) & Cost (Rs.) \\
\hline \multicolumn{5}{|c|}{ I. Working cost } \\
\hline 1. & $\begin{array}{l}\text { Interest @ } 10 \% \text { on fixed assets } \\
\text { of Rs. } 5250 / \text { - for one day. }\end{array}$ & & & 1.44 \\
\hline 2. & Ethylene cylinder & $1.0 \mathrm{~L}$ & 160/cylinder & 160.00 \\
\hline \multirow[t]{2}{*}{3.} & Bio-safe & $200 \mathrm{ml}$ & $850 /$ lit & 170.00 \\
\hline & Total & - & - & 331.44 \\
\hline \multicolumn{5}{|c|}{ II. Variable cost } \\
\hline \multirow[t]{4}{*}{1.} & Labour & - & - & 224.00 \\
\hline & Total & & & 224.00 \\
\hline & Total cost (Rs) for $800 \mathrm{~kg}$ & & & 555.44 \\
\hline & Total cost (Rs) for $1 \mathrm{~kg}$ & & - & 0.69 \\
\hline
\end{tabular}

Assets: Ripening chamber of capacity $800 \mathrm{~kg}$

It might be due to release of sugars by hydrolysis of starch reserve during ripening stage. The results are also supported by Sakhale et al., (2006), William, (2009), Pandarinathan and Sivakumar (2010), Bhatt et al., (2012). Zagade and Relekar (2014) and Patel et al., (2015) in mango fruit.

\section{$\beta$ carotene $(\mu \mathrm{g} / 100 \mathrm{~g})$}

At the initial stage, the $\beta$ carotene content of mango fruit was found to be $268.00 \mu \mathrm{g} / 100 \mathrm{~g}$. At the end of $2^{\text {nd }}, 4^{\text {th }}, 6^{\text {th }}$ and $8^{\text {th }}$ day of storage, treatment $\mathrm{T}_{4}$ recorded maximum $\beta$ carotene content $(6074.30,10274.85,14760.08$ and $15900.33 \mu \mathrm{g} / 100 \mathrm{~g}$ ) followed by treatment $\mathrm{T}_{3}$ (3614.30, 5805.37, 8736.22 and 13950.21 $\mu \mathrm{g} / 100 \mathrm{~g}$ ) in ethylene gas exposure treatment in the ripening chamber.

At the end of $2^{\text {nd }}, 4^{\text {th }}, 6^{\text {th }}$ and $8^{\text {th }}$ day of storage, treatment $\mathrm{T}_{7}$ recorded maximum $\beta$ carotene content $(5486.30,9286.23,13100.02$ and $14300.21 \mu \mathrm{g} / 100 \mathrm{~g}$ ) followed by treatment $\mathrm{T}_{6}$ (3194.34, 5064.45, 7684.58 and 11570.25 $\mu \mathrm{g} / 100 \mathrm{~g}$ ) in ethephon dip treatments.

This might be due to accelerated biosynthesis with chlorophyll degradation and increase in carotene was accompanied by a decrease in acid and increase in sugar content. The results are in line with those reported by Dhemre (2001) in Kesar mango.

\section{Sensory quality}

The data on effect of ethylene gas exposure treatment in the ripening chamber as compared to ethephon dip treatments on changes in sensory quality are presented in Table 3and 4 . The sensory quality of mango $\mathrm{Cv}$. Kesar was influenced by different ethylene gas exposure treatments in ripening chamber and ethephon dip treatments.

The organoleptic rating of mango $\mathrm{Cv}$. Kesar in terms of overall acceptability on $6^{\text {th }}$ day of storage was found to be maximum in the treatment $T_{3}$ (8.77) followed by the treatment $\mathrm{T}_{4}$ (8.46) and treatment $\mathrm{T}_{2}$ (8.37) in ethylene gas exposure treatments in ripening chamber. Whereas the mango fruits treated with ethephon dip treatments recorded the highest overall acceptability in treatment $\mathrm{T}_{7}$ (8.25) followed by treatments $\mathrm{T}_{6}(8.06)$ and $\mathrm{T}_{5}$ (7.93). The lowest sensory score was recorded in the treatment $\mathrm{T}_{1}(6.50)$ i.e. control.

Similarly, the organoleptic rating of mango $\mathrm{Cv}$. Kesar in terms of overall acceptability on 
$8^{\text {th }}$ day of storage was found to be maximum in the treatment $\mathrm{T}_{6}$ (8.66) followed by the treatment $\mathrm{T}_{5}(8.18)$ and treatment $\mathrm{T}_{7}$ (7.91) in ethephon dip treatments. Whereas the mango fruits treated in ethylene gas exposure treatments in ripening chamber recorded the maximum sensory score in treatment $\mathrm{T}_{2}(8.40)$ followed by treatments $\mathrm{T}_{3}$ (8.10) and $\mathrm{T}_{4}$ (7.85).The lowest sensory score was recorded in the treatment $\mathrm{T}_{1}(7.22)$ i.e. control.

The uniform and sustainable colour development of the fruit during ripening may be associated with faster degradation of chlorophyll and functional activity of ethylene as a degreening agent. Generally the distinct flavor development is function of adequate sugar acid blend coupled with suitable combination of other bio-chemicals and volatiles, which might have developed adequately during the ethylene, induced ripening of fruits.

Similar findings were recorded by Dhemre (2001) in mango Cv. Kesar, Daware (2012), Zagade and Relekar (2014), Venkatram and Pandiarajan (2014) in mango Cv. Alphonso.

\section{Cost of ripening of Kesar mango fruits}

It could be observed from the Table 5 that the cost of ripening of $1 \mathrm{~kg}$ mango fruits was worked on per day basis. The cost of ripening chamber for $800 \mathrm{~kg}$ fruits on per day interest and ethylene gas was considered for calculating the cost of ripening. The cost was found to be Rs 0.69 per $\mathrm{kg}$.

It was found that mango $\mathrm{Cv}$. Kesar exposed to the ethylene gas in the ripening chamber and ethephon dip treatment triggered the ripening process. It was also noticed that more the period of exposure to ethylene gas and more the concentration of ethephon, faster was the ripening process and showed the significant increasing trends in TSS, sugars, $\beta$ carotene and decreasing trends in titratable acidity and ascorbic acid in all the treatment combinations during advancement of storage period in ambient condition.

It was observed that mango fruits $\mathrm{Cv}$. Kesar ripened by exposing them to $100 \mathrm{ppm}$ ethylene gas in ripening chamber for $18 \mathrm{hrs}$ and storage at ambient condition recorded the maximum shelf life of 6 days and showed better results in respect of high overall acceptability score of 8.77. Similarly, mango fruits Cv. Kesar ripened by ethephon dip treatment of $750 \mathrm{ppm}$ for 5 minutes and storage at ambient condition recorded the maximum shelf life of 8 days and showed better results in respect of high overall acceptability score of 8.66 , respectively.

\section{References}

Anonymous, 2014. Indian Horticulture Database - 2014. National Horticulture Board, Ministry of Agriculture, Government of India, Gurgaon, INDIA.pp.2-3.

Bhatt, A., N.K. Mishra, D.S. Mishra, and C.P. Singh.2012. Foliar application of potassium, calcium, zinc, and boron enhance yield, quality, and shelf life of mango. Hortflora res. Spectrum. 1(4): 300-305.

Daware, P. M. 2012. Studies on period of exposure to ethylene gas in $\mathrm{KKV}$ fruit ripening chamber on storage behavior of mango (Mangifera indica L.) $\mathrm{Cv}$. Alphonso, Thesis M Sc (Ag). Dr. Balasaheb Sawant Konkan Krishi Vidyapeeth, Dapoli, Maharashtra, India.

Deepa, J. and P. Preetha. 2014. Influence of Exposure Time, Temperature and Ethylene Concentration on The Ripening of Mango Fruits. Trends in Biosciences 7(20): 3260-3267.

Dhemre, J.K. 2001.Studies on extending the shelf life of mango (Mangifera indica 
L.) Cv. Kesar. Thesis $\mathrm{Ph} \mathrm{D}(\mathrm{Ag})$. Mahatma Phule Krishi Vidyapeeth, Rahuri, Maharashtra, India.

Pandarinathan, S. and S.Sivakumar. 2010. Studies on biochemical changes in mangoes due to artificial ripening. Int. J. Agri. Sci. 1: 347-355.

Panse, V. G. and P. V. Sukhatme.1995. Statistical Methods for Agricultural Workers. $4^{\text {th }}$ Edn. I.C.A.R., New Delhi.

Patel, U., D.K., Varu, and J.Chaudhari. 2015. Effect of pre-harvest spray of chemicals on shelf-life and quality of mango $\mathrm{Cv}$. Kesar. Asian J. of Hort.10 (2): 187-193.

Pujari, K.H. and V.B. Mehta. 2010. Low cost ripening chamber for mango. A paper presented in International mango symposium 2010 held at Sanya China.

Sakhale, B. K., V. N. Pawar, and B. M. Kapse. 2006. Effect of Ethrel on Hastening of Onset of Ripening in Kesar Mango (Mangifera indica L.). In Proceedings of $8^{\text {th }}$ International Mango Symposium, February 2006, 820: 635-
642.

Singh, P., M.K. Singh, M. Kumar, and S. Malik. 2012. Effect of physic-chemical treatment on ripening behaviour and post-harvest quality of Amrapali Mango (Mangifera indica L.) during storage. J. Environ. Bio., 33: 227-232.

Venkatram, P. and T. Pandiarajan. 2014. Optimization of Ethylene Concentration and Exposure Time for the Ripening of Mango var. Alphonso in Farm Level Ripening Chamber. Trends in Biosciences 7(24): 4259-4263.

William, O. A., O. Ibok, and O. E. William. 2009. Effect of Ethy-Gen II $^{\circledR}$ ripening concentrate on ripening and sensory properties of mangoes (Mangifera indica L.). Pakistan Journal Nutrition, 8 (10):1641-1644.

Zagade, V.V and P.P. Ralekar. 2014. Chemical composition, ripening behavior and organoleptic quality of mango $\mathrm{Cv}$. Alphonso as influenced by period of maturity. Plant Archives. 14(2):751-756.

\section{How to cite this article:}

Doke, N.D., J.K. Dhemre and Kad, V.P. 2018. Effect of Ethylene on Qualitative Changes during Ripening of Mango (Mangifera indica L.) cv. Kesar. Int.J.Curr.Microbiol.App.Sci. 7(02): 1563-1571. doi: https://doi.org/10.20546/ijcmas.2018.702.188 